\title{
PENGARUH FORMULASI MALTODEKSTRIN DAN TWEEN 80 PADA KARAKTERISTIK FISIKOKIMIA BUMBU HERBAL INSTAN
}

\author{
[Influence of Maltodextrin and Tween 80 Formulations on Physicochemical Properties of \\ Instant Herbal Spices]
}

\author{
Eva Mayasari*, Tri Rahayuni, Jessi Manalu \\ Program Studi Ilmu dan Teknologi Pangan, Fakultas Pertanian, Universitas Tanjungpura, Pontianak \\ Email : eva.mayasari@faperta.untan.ac.id
}

Diterima 27 Juni 2019/ Disetujui 13 November 2019

\begin{abstract}
Herbal spices used in making instant spices are sansakng leaf (Albertisia papuana Becc.), onion, and garlic. The drying method in making instant spices uses the foam mat drying method. The purpose of this study was aimed to determine the effect of maltodextrin and tween 80 formulations on instant herbal spices and determine the best formulation of maltodextrin and tween 80 formulations added on instant herbal spices based on physical and chemical properties. This study used a randomized block design (RBD) factorial pattern which is consisted of two factors of maltodextrin $(5 \%, 10 \%, 15 \%)$ and tween $80(0.5 \%$ and $1 \%)$, each treatment was replicated four times. The ANOVA $(\mathrm{a}=5 \%)$ results showed that the addition of maltodextrin on intant herbal spices significantly affected on moisture content, water absorption, water activity, and yield. While the addition of tween 80 on intant herbal spices significantly affected on moisture content and water activity. The best treatment on physicochemical properties showed in the combination of maltodextrin 5\% and tween $801 \%$.
\end{abstract}

Keywords: Albertisia papuana Becc., foam mat drying, maltodextrin, sansakng, tween 80

\section{ABSTRAK}

Bumbu herbal yang digunakan pada pembuatan bumbu instan adalah daun sansakng (Albertisia papuana Becc.), bawang merah, dan bawang putih. Metode pengeringan dalam pembuatan bumbu instan menggunakan metode foam mat drying. Penelitian ini bertujuan untuk mengetahui pengaruh formulasi maltodekstrin dan tween 80 pada bumbu herbal instan dan menentukan formulasi yang tepat dari formulasi maltodekstrin dan tween 80 pada pembuatan bumbu herbal instan berdasarkan sifat fisik dan kimia. Penelitian ini menggunakan rancangan acak kelompok (RAK) pola faktorial dengan dua faktor, yaitu konsentrasi maltodekstrin (5\%, 10\% 15\%) dan konsentrasi tween 80 (0,5\% dan 1\%), masing-masing perlakuan diulang sebanyak empat kali. Parameter pengamatan yang diukur adalah karakteristik fisik dan kimia bumbu herbal instan. Hasil ANOVA ( $a=5 \%)$ menunjukkan bahwa penambahan maltodekstrin pada bumbu herbal instan berpengaruh nyata terhadap terhadap kadar air, daya serap air, aktivitas air dan rendemen bumbu herbal instan. Sedangkan penambahan tween 80 berpengaruh nyata terhadap kadar air dan aktivitas air. Kombinasi maltodekstrin sebanyak 5\% dan tween 80 sebanyak $1 \%$ merupakan perlakuan terbaik berdasarkan karakteristik fisikokimia.

Kata Kunci: Albertisia papuana Becc, foam mat drying, maltodekstrin, sansakng, tween 80

\section{PENDAHULUAN}

Definisi bumbu herbal adalah bumbu yang berasal dari bagian tumbuh-tumbuhan, seperti akar, batang, daun, buah, bunga maupun biji yang juga dikenal sebagai rempah-rempah. Bumbu dapat bersifat herbal karena selain fungsinya sebagai penyedap masakan (meningkatkan citarasa makanan), bumbu ini juga bermanfaat untuk kesehatan (Hambali dkk., 2008).

Bawang putih dan bawang merah merupakan bumbu herbal, karena mengadung senyawa antibakteri yaitu alisin. Alisin dapat merusak protein kuman penyakit sehingga kuman penyakit tersebut mati (Gobel, 2012). Daun sansakng merupakan salah satu penyedap alami khas suku Dayak, Kalimantan Barat, Indonesia. 
Daun ini memiliki kandungan senyawa asam amino glutamat bebas yang bertanggungjawab terhadap rasa gurih (umami) pada masakan (Mayasari dkk., 2017). Lusiana dkk. (2013) melaporkan bahwa daun ini dapat menghambat pertumbuhan parasit Plasmmodium falciparum.

Kelemahan dalam pemanfaatan bumbu herbal dalam bentuk segar diantaranya adalah kurang praktis, mudah terkontaminasi, dan masa simpan singkat. Oleh karena itu, perlu dilakukan upaya pengolahan bumbu herbal ini dalam bentuk instan menggunakan metode pengeringan.

Salah satu metode pengeringan yang banyak dikembangkan untuk bubuk instan adalah foam mat drying. Metode ini memiliki kelebihan yaitu memiliki laju pengeringan yang lebih cepat daripada pengeringan lainnya, suhu pengeringan yang rendah, penguapan air yang cepat, biaya yang lebih rendah serta lebih mudah dalam pengerjaannya (Febrianto dkk., 2012). Metode foam mat drying ini telah banyak dikembangkan untuk produk instan berbentuk bubuk, karena dapat mengeringkan sampel dalam bentuk cairan, misalnya pada pembuatan cabai hijau instan (Mardini dkk., 2016).

Metode foam mat drying yang digunakan dalam proses pengeringan membutuhkan foaming agent (bahan penghasil foam atau busa). Foaming agent yang digunakan dalam penelitian ini adalah tween 80 . Menurut Susanti dkk. (2014) beberapa foaming agent yang sering digunakan adalah putih telur, soda kue, gliserin dan tween. Busa atau foam yang dihasilkan dari foaming agent akan mempercepat proses pengeringan. Beberapa jenis tween yaitu tween $20,40,65$ dan 80, setiap tween memiliki fungsi yang berbeda tergantung nilai HLB-nya. Tween 80 memiliki nilai HLB 15 yang stabil pada air dan minyak sehingga dapat digunakan sebagai bahan emulsifier.

Rempah-rempah memiliki senyawa yang karakteristiknya berbeda, misalnya larut dalam air atau minyak. Pembuatan bumbu instan diperlukan emulsifier untuk menyatukan senyawa yang memiliki karakteristik berbeda. Oleh karena itu, foaming agent yang digunakan dalam penelitian ini adalah tween 80 . Selain itu, tween 80 juga dapat berfungsi sebagai bahan pengemulsi, sehingga dapat membantu proses ekstraksi bumbu herbal.

Maltodekstrin digunakan sebagai bahan pengisi (filler) dalam pembuatan bumbu herbal instan. Penambahan maltodekstrin diyakini dapat melindungi senyawa kimia yang terdapat pada bahan. Menurut Fiana dkk. (2016), maltodekstrin memiliki kemampuan meningkatkan volume bahan dan melindungi komponen aktif pada bahan. Maltodekstrin akan melindungi bumbu herbal selama proses pengeringan.

Tujuan dari penelitian ini adalah untuk mengetahui pengaruh formulasi maltodekstrin dan tween 80 pada bumbu herbal instan dan menentukan formulasi yang tepat dari formulasi maltodekstrin dan tween 80 pada pembuatan bumbu herbal instan berdasarkan sifat fisik dan kimia.

\section{BAHAN DAN METODE}

\section{Rancangan Penelitian}

Rancangan penelitian ini menggunakan Rancangan Acak Kelompok (RAK) pola faktorial dengan 2 faktor kombinasi yaitu konsentrasi maltodekstrin sebanyak 5\%, $10 \%$ \& $15 \%$ dan konsentrasi tween 80 sebanyak $0,5 \%$ \& $1 \%$. Masing-masing perlakuan diulang sebanyak empat kali sehingga diperoleh 24 kombinasi perlakuan.

\section{Bahan}

Bahan yang digunakan dalam pembuatan bumbu herbal instan adalah daun san-sakng diperoleh dari Desa Palo Kecamatan Jelimpo Kabupaten Landak, Provinsi Kalimantan Barat, Indonesia, bawang merah, bawang putih, garam dapur dan akuades.

\section{Alat}

Alat yang digunakan dalam penelitian ini adalah timbangan digital, hot plate, penyaring vakum, magnetik stirer, spatula besi, gelas beaker, toples, sendok, penggiling bawang, blender, ayakan 40 mesh dan pengering kabinet.

\section{Preparasi Sampel}

Daun sansakng yang telah disortasi kemudian dikering anginkan pada suhu $\pm 37^{\circ} \mathrm{C}$ selama \pm 72 jam. Daun yang telah kering 
selanjutnya dihaluskan menggunakan blender untuk mencapai ukuran serbuk 40 mesh. Serbuk halus daun tersebut digunakan sebagai sampel dalam proses ekstraksi selanjutnya.

Bawang merah dan bawang putih dikeringkan dengan menggunakan pengering kabinet pada suhu $35^{\circ} \mathrm{C}$ selama 24 jam. Bawang yang telah kering kemudian dihaluskan dengan blender dan diayak dengan ayakan 40 mesh sehingga diperoleh serbuk bawang merah dan serbuk bawang putih.

\section{Pembuatan Bumbu Herbal Instan}

Setiap bahan diekstraksi menggunakan metode infusi menurut Mayasari dan Jessi. M (2019). Bubuk kering bumbu dilarutkan dalam pelarut akuades panas suhu $90^{\circ} \mathrm{C}$ selama 15 menit diaduk menggunakan magnetik stirer. Perbandingan antara bahan dan pelarut adalah $1: 100(\mathrm{~g} / \mathrm{ml})$. Persentase bahan yang digunakan diantaranya : bubuk daun sansakng $40 \%$, bubuk bawang putih $25 \%$, bubuk bawang merah $25 \%$ dan garam $10 \%$.

Hasil ekstraksi bumbu herbal kemudian disaring untuk memisahkan ekstrak dengan endapan-endapan yang tidak larut. Setelah itu, ekstrak bumbu akan dicampurkan dengan maltodekstrin dan tween 80 sesuai konsentrasi, yaitu maltodekstrin sebanyak $5 \%, 10 \%, 15 \%$ dan tween 80 sebanyak $0,5 \%, 1 \%$. Namun, sebelumnya maltodekstrin dipreparasi terlebih dahulu dengan melarutkan maltodekstrin ke dalam akuades yang telah dipanaskan pada suhu $60^{\circ} \mathrm{C}$ dengan perbandingan $1: 1$. Kemudian cairan maltodekstrin tersebut dimasukan bersamaan dengan tween 80 pada ekstrak bumbu dan diaduk menggunakan stirer selama 30 menit.

Ekstrak yang telah dicampurkan maltodekstrin dan tween 80 disaring kembali dengan kertas saring whatman no. 1 untuk memastikan kembali tidak terdapat endapan atau kotoran yang terbawa dari bahan sebelum dikeringkan. Ekstrak yang telah disaring dituangkan ke loyang untuk dikeringkan dengan pengering kabinet pada suhu $\pm 40^{\circ} \mathrm{C}$ selama 36 jam. Sampel yang telah kering akan dihaluskan dan diayak diayak menggunakan ayakan ukuran 100 mesh, maka akan diperoleh bubuk bumbu instan.

\section{Parameter Pengamatan}

Parameter pengamatan yang digunakan pada penelitian ini adalah parameter fisik meliputi analisa kadar air (Sudarmadji, 1997), analisa daya serap air (Firdhausi, dkk., 2015) analisa aktivitas air (Sudarmadji 1997), dan analisa rendemen (Firdhausi, dkk., 2015). Parameter kimia yang diamati adalah asam amino glutamat bebas (Khokhani dkk, 2012).

\section{Analisis Data}

Data hasil analisis yang diperoleh dari penelitian ini dianalisis secara statistik menggunakan analisa sidik ragam (ANOVA) dengan taraf $5 \%$ dan jika hasil diperoleh berpengaruh nyata, maka akan dilanjutkan dengan uji BNJ pada taraf 5\% (Hanafiah, 2003).

\section{HASIL DAN PEMBAHASAN}

\section{Karakteristik Daun Sansakng}

Karakteristik fisik daun san-sakng diataranya adalah kadar air daun san-sakng segar 58,99\%, kadar air daun san-sakng kering $8,57 \%$ dan rendemen bumbu instan daun sansakng kering $11,11 \%$ (Arifin, 2017). Total asam amino bebas ekstrak daun san-sakng 0,4\%, pH ekstrak daun san-sakng 5,3 dan sensori ekstrak daun san-sakng 1,22 (sangat tidak suka). Kadar asam amino bebas ekstrak bumbu adalah $6,7 \%$.

\section{Kadar Air}

Menurut SNI 01-3709-1995, kadar air maksimal untuk bumbu rempah-rempah adalah $12 \%$. Berdasarkan hasil uji ANOVA $(a=0,05)$ diketahui bahwa kombinasi penambahan maltodekstrin dan tween 80 tidak berpengaruh nyata terhadap kadar air bumbu instan. Perlakuan penambahan maltodekstrin berpengaruh nyata terhadap kadar air bumbu instan dan perlakuan penggunan tween 80 juga berpengaruh nyata terhadap kadar air nyata bumbu instan sehingga dilanjutkan dengan uji lanjut BNJ $(a=0,05)$ yang disajikan pada Tabel 1 .

Penambahan maltodekstrin $5 \%$ berbeda nyata, dengan perlakuan maltodekstrin $10 \%$ dan $15 \%$, perlakuan maltodekstrin $10 \%$ juga berbeda nyata dengan perlakuan maltodekstrin $15 \%$ terhadap nilai kadar air bumbu instan. Nilai kadar 
Versi Online:

http://www.profood.unram.ac.id/index.php/profood e-ISSN: 2443-3446

air tertinggi terdapat pada perlakuan maltodekstrin $15 \%$ yaitu $7,79 \%$ dan perlakuan maltodekstrin terendah terdapat pada perlakuan maltodekstrin $5 \%$ yaitu $6,8 \%$.

Tabel 1. Pengaruh Maltodekstrin terhadap Kadar Air Bumbu Herbal Instan (\%)

\begin{tabular}{cc}
\hline $\begin{array}{c}\text { Maltodekstrin } \\
(\mathbf{\%})\end{array}$ & $\begin{array}{c}\text { Rata-rata } \\
\mathbf{( \% )}\end{array}$ \\
\hline 5 & $0,8735^{\mathrm{a}}$ \\
10 & $0,9254^{\mathrm{ab}}$ \\
15 & $1,1533^{\mathrm{c}}$ \\
\hline BNJ $5 \%=0,22$ & \\
\hline
\end{tabular}

Kadar air maltodekstrin adalah 6\% (Astuti, 2009), maltodekstrin dapat mengikat air bebas pada bahan, sehingga kadar air bahan yang ditambahkan maltodekstrin akan meningkat seiring dengan meningkatnya jumlah maltodekstrin yang ditambahkan (Hui, 2002). Oleh karena itu, semakin tinggi konsentrasi maltodekstrin yang ditambahkan pada pembuatan bumbu instan, maka semakin tinggi pula nilai kadar air bumbu instan yang dihasilkan.

Tabel 2. Pengaruh Tween 80 terhadap Kadar Air Bumbu Instan

\begin{tabular}{cc}
\hline Tween 80 (\%) & Rata-rata (\%) \\
\hline 0,5 & $7,57^{\mathrm{a}}$ \\
1 & $7,04^{\mathrm{b}}$ \\
\hline BNJ $(\mathrm{a}=0,05)=0,22$ & \\
\hline
\end{tabular}

Tabel 2 menunjukan bahwa penambahan tween 80 sebanyak $0,5 \%$ berbeda nyata dengan perlakuan tween 80 sebanyak $1 \%$ terhadap nilai kadar air bumbu instan. Nilai kadar air tertinggi terdapat pada perlakuan tween $800,5 \%$ dan nilai kadar air terendah terdapat pada perlakuan tween 80 1\%. Semakin tinggi konsentrasi tween 80 yang digunakan maka nilai kadar air bumbu instan yang dihasilkan semakin rendah. Hal ini dikarenakan penambahan konsentrasi tween 80 yang semakin tinggi akan menghasilkan busa yang semakin banyak sehingga dapat mempercepat proses pengeringan (Kamsiati, 2006). Pengeringan yang cepat akan menghasilkan nilai kadar air yang rendah pada lama pengeringan yang sama. Suatu lapisan busa akan lebih cepat kering daripada cairan yang tidak dalam bentuk busa pada kondisi lingkungan yang sama.

\section{Daya Serap Air}

Analisis secara statistik ANOVA $(a=0,05)$, diketahui kombinasi perlakuan maltodekstrin dan tween 80 tidak berpengaruh nyata terhadap daya serap air bumbu instan. Perlakuan tween 80 juga tidak berpengaruh nyata terhadap nilai daya serap air bumbu instan. Namun perlakuan penambahan maltodekstrin berpengaruh nyata terhadap daya serap air bumbu herbal instan, sehingga dilakukan uji BNJ. Hasil uji BNJ $(a=0,05)$ disajikan pada Tabel 3.

Tabel 3. Pengaruh Maltodekstrin terhadap Daya Serap Air Bumbu Herbal Instan

\begin{tabular}{cc}
\hline $\begin{array}{c}\text { Maltodekstrin } \\
(\%)\end{array}$ & $\begin{array}{c}\text { Rata-rata } \\
(\%)\end{array}$ \\
\hline 5 & $6,66^{\mathrm{a}}$ \\
10 & $5,87^{\mathrm{b}}$ \\
15 & $5,56^{\mathrm{b}}$ \\
BNJ $5 \%=0,50$ &
\end{tabular}

Berdasarkan Tabel 3, diperoleh nilai daya serap air perlakuan maltodekstrin dengan konsentrasi $5 \%$ berbeda nyata dengan perlakuan maltodekstrin konsentrasi $10 \%$ dan $15 \%$. Nilai daya serap air konsentrasi maltodekstrin $10 \%$ berbeda tidak nyata dengan perlakuan maltodekstrin $15 \%$. Nilai daya serap air tertinggi terdapat pada perlakuan konsentrasi maltodekstrin $5 \%$, yaitu sekitar $6,66 \%$ dan nilai daya serap air terendah terdapat pada perlakuan maltodekstrin $15 \%$, yaitu 5,56\%. Semakin tinggi konsentrasi maltodekstrin yang digunakan, maka nilai daya serap air bumbu instan yang dihasilkan semakin rendah. Menurut Arifin (2017), nilai daya serap air suatu bahan berbanding terbalik dengan nilai kadar air bahan, sehingga bahan yang memiliki kadar air yang tinggi akan menghasilkan nilai daya serap air yang rendah.

\section{Aktivitas Air}

Analisis statistik ANOVA $(a=0,05)$ menunjukan bahwa kombinasi perlakuan maltodekstrin dan tween 80 tidak berpengaruh nyata terhadap Aw bumbu instan. Perlakuan tween 80 berpengaruh nyata terhadap Aw 
bumbu instan. Perlakuan maltodekstrin juga berpengaruh nyata terhadap nilai Aw bumbu instan, sehingga dilakukan uji $B N J(a=0,05)$. Hasil analisis $B N J(a=0,05)$ pengaruh konsentrasi maltodekstrin terhadap Aw bumbu instan disajikan pada Tabel 4 dan hasil analisis BNJ $(a=0,05)$ pengaruh konsentrasi tween 80 terhadap Aw bumbu instan disajikan pada Tabel 5.

Nilai Aw bumbu instan perlakuan maltodekstrin $5 \%$ berbeda nyata dengan perlakuan maltodekstrin $10 \%$ dan $15 \%$. Nilai Aw bumbu instan perlakuan maltodekstrin $10 \%$ berbeda nyata dengan perlakuan maltodekstrin $15 \%$. Nilai Aw tertinggi terdapat pada perlakuan maltodekstrin $15 \%$, yaitu 0,615 dan nilai Aw terendah terdapat pada perlakuan maltodekstrin $5 \%$, yaitu 0,596 (Tabel 4). Nilai Aw berbanding lurus dengan nilai kadar air bahan, sehingga nilai kadar air yang tinggi akan menghasilkan nilai Aw bumbu instan yang tinggi pula (Wulandari, 2013).

Tabel 3. Pengaruh Maltodekstrin terhadap Aw Bumbu Herbal instan

\begin{tabular}{cc}
\hline $\begin{array}{c}\text { Penambahan } \\
\text { Maltodekstrin (\%) }\end{array}$ & $\begin{array}{c}\text { Rata-rata } \\
\text { Aw }\end{array}$ \\
\hline 5 & $0,596^{\mathrm{a}}$ \\
10 & $0,604^{\mathrm{b}}$ \\
15 & $0,615^{\mathrm{c}}$ \\
\hline BNJ $5 \%=0,004$ &
\end{tabular}

Nilai Aw bumbu instan perlakuan tween 80 $0,5 \%$ berbeda nyata dengan perlakuan tween 80 $1 \%$. Nilai Aw tertinggi terdapat pada perlakuan tween 80 0,5\% dan nilai Aw terendah terdapat pada perlakuan tween $801 \%$ (Tabel 5). Hubungan antara parameter kadar air dengan aktivitas air pada bahan pangan ditunjukkan dengan semakin tinggi nilai kadar air bahan, maka semakin tinggi pula nilai aktivitas air bahan pangan tersebut (Wulandari, 2013). Hasil data aktivitas air ini sesuai dengan data nilai kadar air bumbu instan, bahwa semakin tinggi konsentrasi maltodekstrin yang digunakan maka semakin tinggi pula nilai kadar air maupun nilai aktivitas air yang dihasilkan. Selain itu, semakin tinggi konsentrasi tween 80 yang digunakan maka nilai Aw bumbu instan semakin rendah.
Tabel 4. Pengaruh Tween 80 terhadap Aw Bumbu Herbal Instan

\begin{tabular}{cc}
\hline $\begin{array}{c}\text { Penambahan } \\
\text { Tween 80 (\%) }\end{array}$ & Rata-rata Aw \\
\hline 0,5 & $0,61^{\mathrm{a}}$ \\
1 & $0,60^{\mathrm{b}}$ \\
\hline BNJ $5 \%=0,004$ & \\
\hline
\end{tabular}

\section{Rendemen}

Hasil ANOVA ( $a=5 \%$ ) menunjukkan bahwa kombinasi maltodekstrin dan tween 80 tidak berpengaruh nyata terhadap rendemen bumbu herbal instan. Perlakuan tween 80 juga tidak berpengaruh nyata terhadap rendemen bumbu herbal instan. Perlakuan maltodekstrin berpengaruh nyata terhadap rendemen bumbu herbal instan, sehingga dilakukan uji lanjut BNJ taraf 5\% (Tabel 6).

Nilai rendemen bumbu instan perlakuan maltodektrin dengan konsentrasi $5 \%$ berbeda nyata dengan perlakuan maltodekstrin dengan konsentrasi $10 \%$ dan $15 \%$. Nilai rendemen tertinggi terdapat pada perlakuan maltodekstrin $15 \%$, yaitu $13,22 \%$ dan nilai rendemen terendah terdapat pada perlakuan maltodkstrin $5 \%$, yaitu $7 \%$. Hasil ini menunjukan bahwa semakin tinggi konsentrasi maltodekstrin yang digunakan dalam pembuatan bumbu instan, maka rendemen yang dihasilkan semakin tinggi pula. Hal ini dikarenakan maltodekstrin merupakan bahan tambahan makanan yang berupa padatan, sehingga penambahan maltodekstrin pada bahan dapat meningkatkan total padatan pada bahan pangan yang akan dikeringkan (Wuryantoro dan Wahono, 2014), sehingga rendemen bahan yang dihasilkan setelah pengeringan menjadi meningkat. Oleh karena itu, penambahan maltodekstrin dengan konsentrasi yang tinggi dan terlarut akan meningkatkan nilai rendemen bumbu instan.

Tabel 6. Pengaruh Maltodekstrin terhadap Rendemen Bumbu Herbal Instan

\begin{tabular}{|c|c|}
\hline $\begin{array}{c}\text { Maltodekstrin } \\
(\mathbf{\%})\end{array}$ & $\begin{array}{c}\text { Rata-rata } \\
\mathbf{( \% )}\end{array}$ \\
\hline 5 & $7,00^{\mathrm{a}}$ \\
\hline 10 & $10,44^{\mathrm{b}}$ \\
\hline 15 & $13,22^{\mathrm{c}}$ \\
\hline BNJ $5 \%=0,65$ & \\
\hline
\end{tabular}


Versi Online:

http://www.profood.unram.ac.id/index.php/profood e-ISSN: 2443-3446

\section{Total Asam Amino Glutamat Bebas}

Hasil ANOVA $(a=5 \%)$ diperoleh bahwa perlakuan kombinasi maltodekstrin dan tween 80 berpengaruh tidak nyata terhadap total asam amino glutamat bebas bumbu herbal instan. Masing-masing perlakuan maltodekstrin dan tween 80 juga tidak berpengaruh nyata terhadap total asam amino glutamat bebas bumbu herbal instan. Hasil rerata persentase total asam amino glutamat bumbu herbal instan disajikan pada Gambar2. Persentase total asam amino glutamat bebas bumbu herbal instan berkisar antara 3,8\%$5,2 \%$. maltodekstrin diduga dapat melindungi komponen asam amino glutamat bebas selama proses pengeringan. Pernyataan ini sesuai dengan pernyataan Baharuddin (2006), bahwa penggunaan maltodekstrin pada proses enkapsulasi dapat melindungi senyawa kimia pada bahan pangan, terutama senyawa yang mudah teroksidasi oleh panas, maltodekstrin juga dapat melindungi stabilitas flavor selama proses pengeringan.

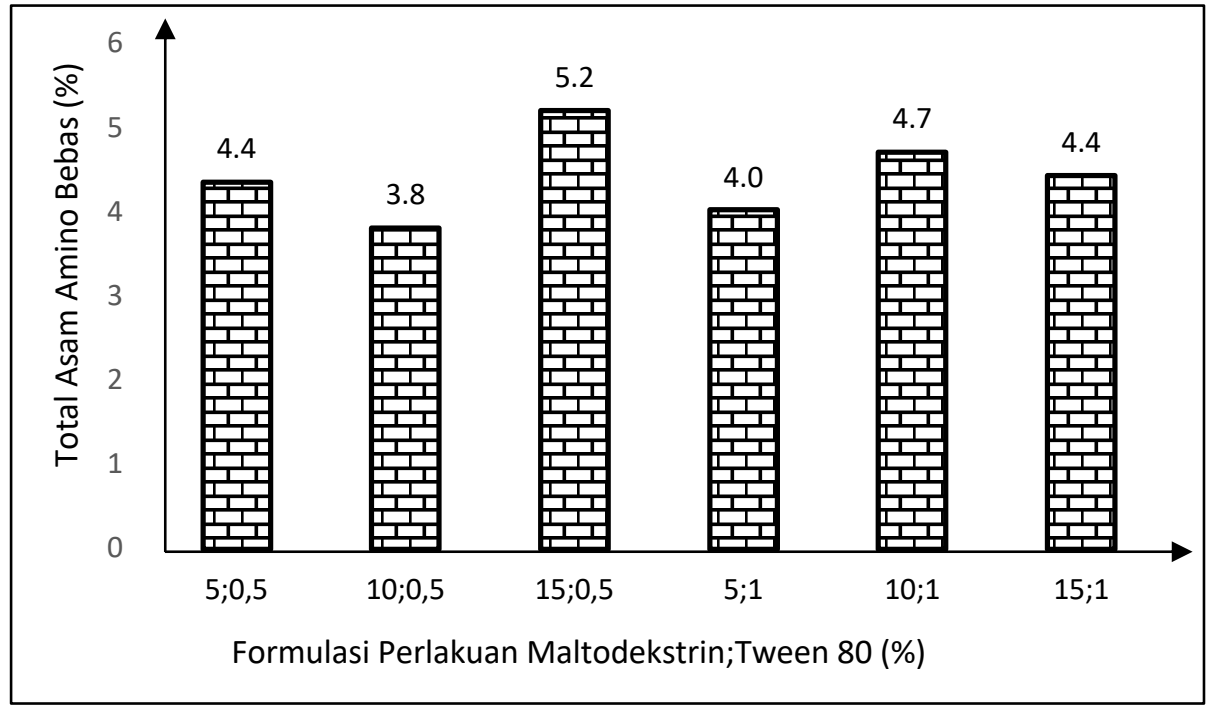

Gambar 1. Rerata Total Asam Amino Glutamat Bebas Bumbu Herbal Instan

\section{KESIMPULAN}

Hasil analisis ANOVA menunjukkan bahwa kombinasi penambahan maltodekstrin dan tween 80 bumbu herbal instan tidak berpengaruh nyata terhadap parameter fisikokimia. Namun penambahan maltodekstrin berpengaruh nyata terhadap kadar air, daya serap air, aktivitas air dan rendemen bumbu herbal instan. Sedangkan penambahan tween 80 berpengaruh nyata terhadap kadar air dan aktivitas air. Kombinasi maltodekstrin sebanyak $5 \%$ dan tween 80 sebanyak $1 \%$ merupakan perlakuan terbaik berdasarkan karakteristik fisikokimia.

\section{UCAPAN TERIMA KASIH}

Penulis mengucapkan terima kasih kepada Ketua Program Studi Ilmu dan Teknologi Pangan serta seluruh Civitas Akademika Fakultas Pertanian Universitas Tanjungpura.

\section{DAFTAR PUSTAKA}

Arifin, Z. 2017. Karakteristik Fitokimia dan Sensori Bumbu Instan Ekstrak Daun Sansakng (Albertisia papuana Becc.) dengan Penambahan Maltodekstrin dan $0,6 \% \mathrm{NaCl}$ pada Proses Pengeringan. [SKRIPSI]. Fakultas Pertanian Universitas Tanjungpura Pontianak.

Astuti, YP. 2009. Maltodekstrin. [Online]. www.empuz.wordpress.com. (Diakses 18 Februari 2019).

Baharuddin, T. 2006. Penggunaan Maltodekstrin pada Yoghurt Bubuk Ditinjau dari Uji Kadar air, Keasaman, pH, Rendemen, Reabsorpsi Uap Air, Kemampuan Keterbasahan dan Sifat Kedispersian. [Laporan Penelitian]. Fakultas Peternakan Universitas Brawijaya Malang. 
Versi Online:

http://www.profood.unram.ac.id/index.php/profood

ISSN: 2443-3446

Febrianto, A, Kumalaningsih, S, dan Aswari, A. W, 2012. Process Engineering of Drying Milk Powder With Foam mat drying Method, A Study of the Effect of the Concentration and Types of Filler. J. Bas Appl. Sci. Res 2(4)3883592.

Fiana R.M., Wenny S.M dan Afi, A. 2016. Pengaruh Konsentrasi Maltodekstrin terhadap Mutu Minuman Instan dari Teh Kombucha. Jurnal Teknologi Pertanian Andalas, Vol.20 No.2.

Gobel, R.A. 2012. Studi Pembuatan Bumbu Inti Sambal Kering. [SKRIPSI]. Universitas Hasanuddin Makassar.

Hambali, E., Fatmawati, dan R. Permanik. (2008). Membuat Aneka Bumbu Instan Kering. Penebar Swadaya. Jakarta.

Hanafiah, K.A. 2003. Rancangan Percobaan Teori dan Aplikasi. Raja Grafindo Persada. Jakarta.

Hui, Y. 2002. Encylopedia of Food Science and Technology Handbook. IVCH Publisher, inc. NewYork.

Lusiana, H., Irwandi, T.T. dan Suparto, I. H. 2013. Uji Anti Plasodium Senyawa Alkaloid dari Albertisia papuana Becc. Prosiding SNKTI (2013) Vol.1 hal-75-78 ISSN: 2088 -9828.

Mardini, A.F.W., Rosidah, U., dan Priyanto, G. 2016. Pembuatan Sambal Cabai Hijau Instan dengan Metode Foam mat drying. Prosiding Seminar Nasional Lahan Suboptimal, Palembang : 2021 Oktober 2016. Hal. 464-489.

Mayasari, E., dan Jessi Manalu. 2019. Karakteristik Sensoris Dan Kimia Bumbu Instan Dari Formulasi Bumbu Herbal Menggunakan Maltodekstrin Dan Tween 80 Pada Proses Pengeringan. Jurnal Ilmiah Teknosains. Vol. V. No. 1. Hal 35-40.

Mayasari, E., Oke A.L., Satrijo, S., dan Maria, U. 2017. Pembuatan Bumbu Instan dari Ekstrak Daun San-sakng (Albertisia papuana Becc.) sebagai Alternatif Penyedap Alami. Prosiding PIPT Universitas Tanjungpura.

Purwayanti, S., Umar, S., Supriyadi dan Murdijati, G. 2013. Umami potential from crude extract of Bekkai lan (Albertisia papuana Becc.) leaves, an indegenous plant in East KalimantanIndonesia. International Food Research Journal. Vol. 20. No. 2: p. 545-549.

Wulandari, A. 2013. Prediksi Umur Simpan Kerupuk Kemplang dalam Kemasan Plastik Polipropilen
Pro Food (Jurnal Ilmu dan Teknologi Pangan)

Vol 5 No. 2 November 2019 eISSN: 2443-1095

Ketebalan $0,3 \mathrm{~mm}, 0,5 \mathrm{~mm}$ dan $0,7 \mathrm{~mm}$. [SKRIPSI]. Fakultas Pertanian Universitas Lampung.

Wuryantoro, H. dan Wahono, H.S. 2014. Penyusun SOP Industri Rumah Tangga Pemanis. Jurnal Pangan dan Agroindustri Vol. 2 No. 3 p. 76-87. 